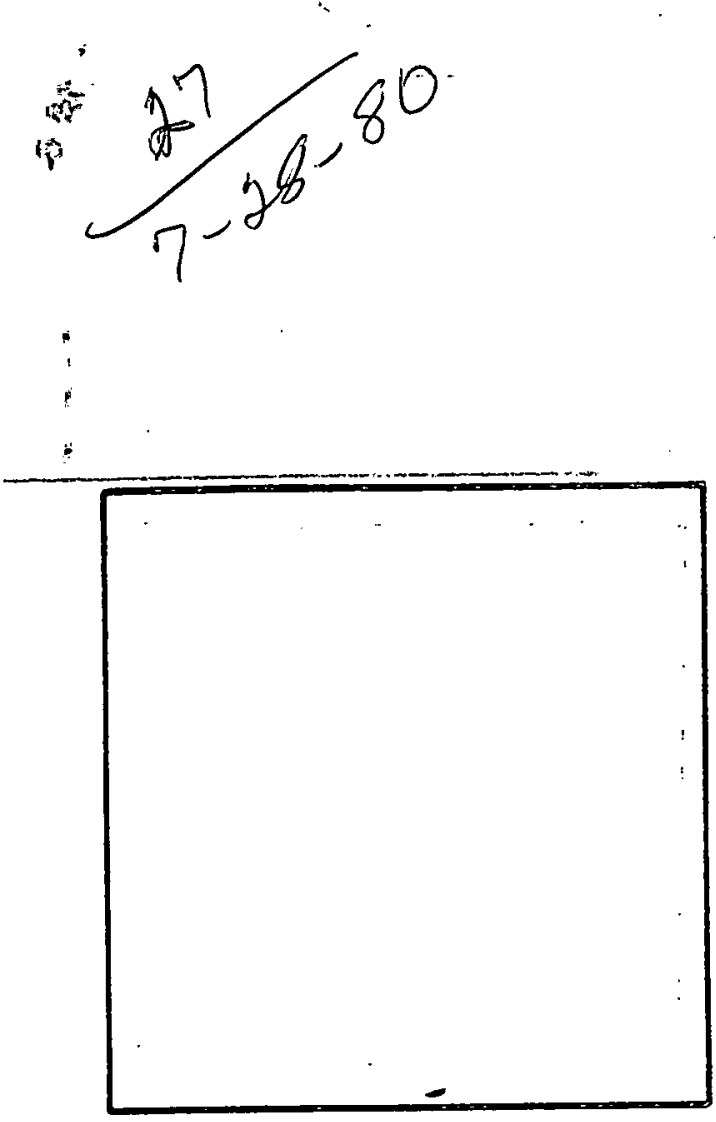

BDX-613-2411

\title{
X-Ray Fluorescence Analysis of Metal Concentration in an Alloy Electroplating Bath
}

\author{
By R. A. Hines
}

Published June 1980

Topical Report

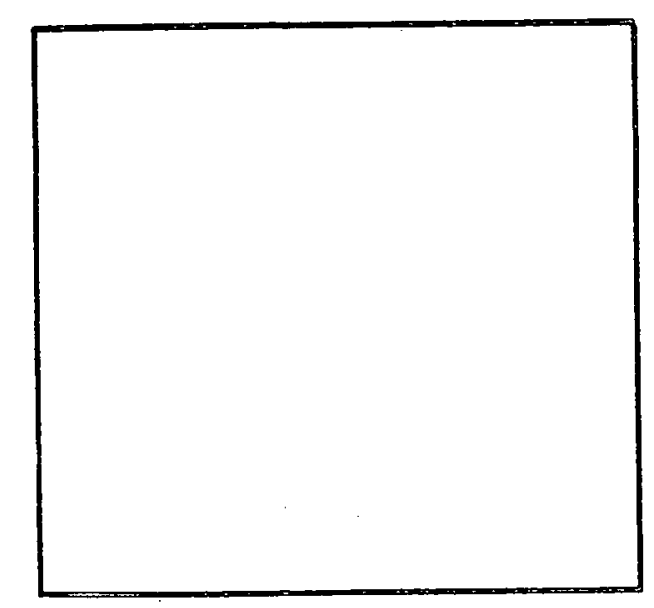

Prepared for the United States Department of Energy Under Contract Number DE-AC04-76-DPO0613. 


\section{DISCLAIMER}

This report was prepared as an account of work sponsored by an agency of the United States Government. Neither the United States Government nor any agency Thereof, nor any of their employees, makes any warranty, express or implied, or assumes any legal liability or responsibility for the accuracy, completeness, or usefulness of any information, apparatus, product, or process disclosed, or represents that its use would not infringe privately owned rights. Reference herein to any specific commercial product, process, or service by trade name, trademark, manufacturer, or otherwise does not necessarily constitute or imply its endorsement, recommendation, or favoring by the United States Government or any agency thereof. The views and opinions of authors expressed herein do not necessarily state or reflect those of the United States Government or any agency thereof. 


\section{DISCLAIMER}

Portions of this document may be illegible in electronic image products. Images are produced from the best available original document. 
This report was prepared as an account of work sponsored by the United States Government. Neither the United States nor the United States Department of Energy, nor any of their employees, nor any of their contractors, subcontractors, or their employees, makes any warranty, express or implied, or assumes any legal liability or responsibility for the accuracy, completeness or usefulness of any information, apparatus, product or process disclosed, or represents that its use would not infringe privately owned rights.

Printed in the United States of America

Available From the National Technical Information Service, U.S. Department of Commerce, 5285 Port Royal Road, Springfield, Virginia 22161.

Price: Microfiche $\$ 3.00$

Paper Copy $\$ 4.50$ 
BDX-613-2411

Distribution Category UC-38

\section{X-RAY FLUORESCENCE ANALYSIS OF METAL CONCENTRATION IN AN ALLOY ELECTROPLATING BATH}

By R. A. Hines

Published June 1980

Topical Report

R. A. Hines, Project Leader

Project Team:

L. H. Bergthold 
X-RAY FLUORESCENCE ANALYSIS OF METAL CONCENTRATION IN AN ALLOY ELECTROPLATING BATH

BDX-613-2411, Topical Report, Published June 1980.

Prepared by $R$, A. Hines

An energy-dispersive X-ray fluorescence analysis system has been developed for rapid, simultaneous analysis of gold and copper concentrations in an aqueous electroplating bath. The speed and repeatability of the system make it well suited for in-process control.. Data collection and reduction are automatic. The analysis requires less than 10 minutes from taking the sample to printing the gold and copper concentrations.

TWL/bjk

This report was prepared as an account of work sponsored by the United States Government. Neither the United States, nor the United States Depertment of Energy, nor any of their employees, nor any of their contractors, subcontractors, or their employees, makes any warranty, expressed or implied or assumes any legal liability or responsibility for the accuracy, completeness or usefulness of any information, apparatus, product, or process disclosed. or represents that its use would not infringe privately owned rights.
The Bendix Corporation Kansas City Division P. O. Box 1159 Kansas City, Missouri 64141

\footnotetext{
A prime contractor with the United States Departmeni of Energy under Contract Number DE-AC04-76-DP00613
} 


\section{CONTENTS}

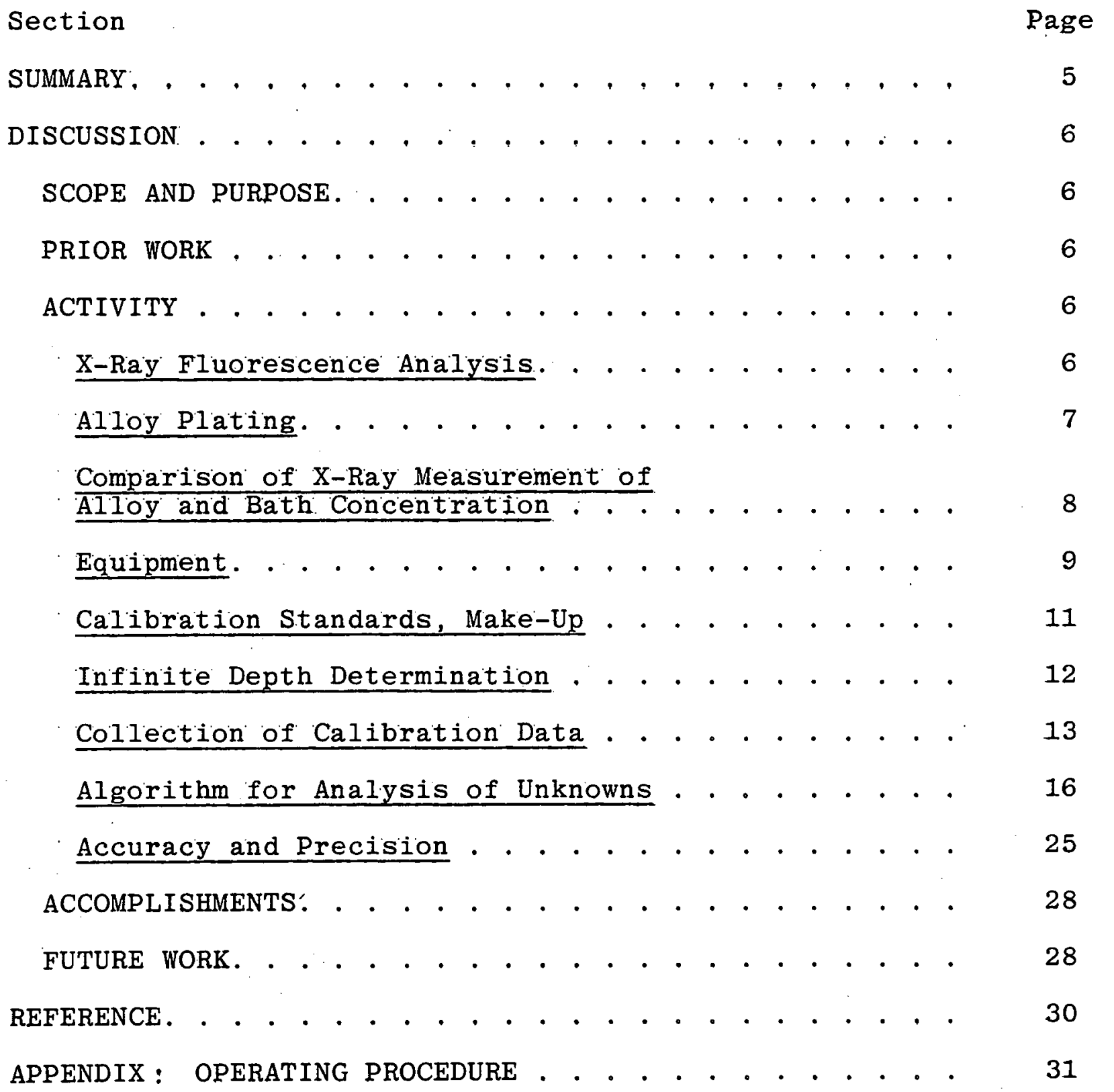




\section{i \\ ILLUSTRATIONS}

Figure

Page

1

X-Ray Analysis Equipment (P-94429) . . . . .

10

Heated Sample Holder (P-99426) . . . . . .

11

3 Infinite Depth Determination . . . . . . . .

14

\section{4}

Gold Calibration Curve . . . . . . . . . .

19

\section{5}

Copper Calibration Curve . . . . . . . . . 20

Gold Matrix Effect . . . . . . . . . . .

21

7

\section{8}

Copper Matrix Effect

22

Flow Chart of Iterative Method . . . . . . . . 24

9

Gold and Copper Calibration Surface. . . . .

\section{TABLES}

Number

Page

1

Analysis of Gold Salts and Copper Concentrate. . . . . . . . . . . . . .

Measured Intensities and Calculated Concentrations . . . . . . . . . . . . .

Absolute and Relative Percent Error. . . .

Effect of Count Time and Analysis Method on Accuracy . . . . . . . . . . 
SUMMARY

A system based on X-ray fluorescence has been developed for determining the metal concentration in an alloy electroforming bath. A radioactive source supplies the excitation energy to a bath sample, and the intensities of the characteristic $X$-ray spectrum for gold and copper are measured using a solid-state detector and a multichannel analyzer. A programmable calculator reads the spectrum and converts the data to metal concentrations.

The basic hardware system was developed previously for alloy analysis, and only the addition of a heated sample holder was required for this work. After developing a suitable algorithm for data reduction, the calculator was programmed to reduce the data.

Twenty-one calibration bath samples with various gold and copper concentrations were carefully prepared. The minimum solution depth required in the sample holder was experimentally determined. Calibration standards were placed in the sample holder, and 500-second counts were used to collect the $\mathrm{X}$-ray spectrum. The Ka radiation from copper and the $L \alpha$ radiation from gold were used.

Two different algorithms were developed to use the calibration data to reduce the intensities from an unknown to gold and copper concentrations. Both methods adjust for source decay and count time variation.

The operating procedure is simple and requires no critical operator measurement. A sample from the bath to be analyzed is placed in a disposable cell and loaded into the heated sample chamber. The count is started, and, when it is complete, the calculator-based data reduction program is run. The program reads and reduces the data and prints the results.

An alloy sample has been prepared to produce a gold and copper spectrum that approximates a standard bath. This sample can be analyzed as if it were a bath sample to determine proper operation and repeatability of the system. The alloy standard is more stable than a liquid bath standard.

The X-ray fluorescence analysis method can be as accurate and precise as standard wet chemistry. In addition, the $\mathrm{X}-\mathrm{ray}$ method is much faster and less susceptible to operator error. 


\section{DISCUSSION}

SCOPE AND PURPOSE

The purpose of this activity was to develop an automated system for reliable and rapid analysis of gold and copper metal concentrations in an alloy electroforming bath. The bath must be maintained at $30 \pm 3 \mathrm{~g} / \mathrm{L}$ gold and $5.3 \pm 0.3 \mathrm{~g} / \mathrm{L}$ copper during electroforming runs. These electroforming runs require a week or more of continuous plating. Accurate analysis of gold concentration in the plating solution is also essential for precious metal inventory and control. Operation simplicity and cost savings also motivated this development for both development and production plating.

This work was limited to the analysis of gold and copper in the alloy bath; however, the basic procedure and equipment could be used for the analysis of other solutions. Most other plating baths, chemical milling, and etch solutions, could be analyzed with this equipment after the construction of calibration curves.

\section{PRIOR WORK}

The analysis of an electroformed gold-copper binary alloy by energy-dispersive X-ray fluorescence analysis was previously established at Bendix Kansas City.' The bath analysis work used existing hardware, which had been upgraded, and some of the existing software. The equipment consists of a radioactive source, a cryogenic cooled detector, a multichannel pulse height analyzer (PHA), and a programmable desk calculator. The operation and calibration. of the PHA and software for reading the raw data from the PHA to the calculator memory are the same for both types of analysis.

Copper exists in the bath as more than one ionic species and simple spectrophotometer measurement had been used to control bath copper concentration. However, because the spectrophotometer method is only sensitive to one of the possible ions, a more complex electrochemical method had to be used for total copper analysis.

\section{ACTIVITY}

$\mathrm{X}$-Ray Fluorescence Analysis

When an electron is removed from an inner shell of an atom a vacancy is created. An electron from an outer shell will then 
make a transition to the lower energy state to fill this vacancy. Each transition will result in the emission of a photon having energy equal to the energy. difference between the shells. If the energy difference is large enough to produce $X$-ray photons, this process is termed X-ray fluorescence. Vacancies can be created in any of the electron shells and can be filled by an electron from any higher energy shell. Since each element has a unique arrangement of electrons, and therefore possible energy transitions, the fluorescent $X$-ray spectrum will be a unique characteristic of that element. The characteristic spectrum of each element is well known and is the basis for X-ray fluorescence analysis.

A variety of methods can be used to generate and analyze the fluorescent radiation. The removal of an inner shell electron can be accomplished by exposing the sample to high energy electrons, $X$-rays, or gama rays from a radioactive source. The resulting fluorescent radiation can be analyzed using a wavelength-dispersive system or an energy-dispersive system. Recent advances in solidstate energy-dispersive detectors coupled with a radioactive source have resulted in small, economical systems. A cadmium 109 radioactive source and a lithium-drifted silicon detector were used for this work.

\section{Alloy Plating}

Bath chemistry control is essential to the gold-copper alloy plating process. The gold concentration in the plating bath is maintained at $30 \pm 3 \mathrm{~g} / \mathrm{L}$ with additions of potassium gold cyanide $\mathrm{KAu}(\mathrm{CN}){ }_{2}$. The copper concentration is maintained at $5.3 \pm 0.3 \mathrm{~g} / \mathrm{L}$ with the addition of a sodium copper chelate, $\mathrm{Na}_{3} \mathrm{Cu}$ DTPA (DTPA, diethylenetriaminepentacetic acid). The gold analysis consisted of removing a $5-\mathrm{mL}$ sample of the bath and precipitation of the gold in a boiling nitric-sulfuric acid solution. The gold precipitate is then filtered, rinsed, dried, and weighed to calculate the gold concentration in the bath. Approximately 6 hours of flow time are required for a gold analysis. For a copper analysis, a 5-mL sample of the bath was diluted with water and the transmittance was measured using a spectrophotometer. The copper concentration was determined from a previously generated calibration curve. This photometer check was only sensitive to $\mathrm{Cu}$ DTPA $^{++}$. After it was learned that other copper ions existed in the bath, new checks for total copper were studied. One check for total copper concentration consisted of electroplating the copper from the solution remaining after precipitating the gold for the gold analysis. The copper is deposited on a platinum cathode and the weight gain of the cathode is used to determine the copper concentration. Other methods for total copper analysis have been tried, but all were relatively complicated. 
An energy-dispersive $\mathrm{X}$-ray. fluorescence analysis system developed for in-process gold-copper alloy measurements had been shown to be a simple, quick, and accurate method for measuring the alloy composition. The alloy composition is determined by measuring the ratio of copper to copper plus gold fluorescent X-ray intensity. Using a previously generated calibration curye, the ratio is converted to percent copper. The success of the alloy measurement and the complications encountered trying to analyze total bath copper concentration motivated the $\mathrm{X}$-ray bath analysis study.

Comparison of $\mathrm{X}$-Ray Measurement of Alloy and Bath Concentration

Many aspects of the bath analysis are identical to the alloy analysis. The elements being studied are gold and copper in both cases; therefore, the same fluorescent $X$-rays are generated and measured. The cadmium 109 source and detector originally chosen for the alloy measurement were equally suitable for the bath analysis. The counting equipment and even the software for determining the intensity of one of the $\mathrm{Cu}$ and one of the $\mathrm{Au}$ $\mathrm{X}$-ray energies are identical.

The differences between alloy analysis and bath analysis complicated the liquid sample analysis. In the alloy analysis a binary alloy is being studied. The gold and copper concentrations are dependent variables; therefore, the alloy composition can be determined from a single parameter. The parameter used for the alloy measurement is the ratio of the measured $\mathrm{Cu} \mathrm{X}$-ray intensity to the sum of measured. $\mathrm{Cu}$ plus $\mathrm{Au} X-\mathrm{Xay}$ intensity.

The individual intensities are a function of the source intensity, count time, and source-to-sample geometry. Since these parameters affect both the $\mathrm{Cu}$ and $\mathrm{Au}$ fluorescence by the same factor, their effect is cancelled in the ratio calculation. The alloy percent copper is then determined from a calibration curve generated by a least squares polynominal fit of alloy percent $\mathrm{Cu}$ to the ratio measured on alloy calibration standards.

In the alloy plating baths, the gold concentration and the copper concentration are independent variables. The individual intensities, and not simply their ratios, must be used to determine the $\mathrm{Au}$ and $\mathrm{Cu}$ concentrations in the bath. Source intensity, count time, and source-to-sample geometry must be considered. Corrections for changes in the source intensity, as a function of time caused by radioactive decay, must be made. The cadmium 109 source has a half-life of 453 days. A count time correction is made to permit count times on bath samples that differ from that used on the calibration samples. Sample geometry is held constant by the heated sample holder. A heated sample holder was required because the gold-copper plating bath operates at $71^{\circ} \mathrm{C}$ and will begin to salt out as the solution cools to room temperature. 
The gold intensity from a bath sample not only is a function of gold concentration, but also is affected to a lesser degree by the copper concentration. The copper intensity is similarly a function of both the gold and copper concentration. For a constant gold concentration, increasing copper concentration reduces the gold fluorescence. This matrix effect must be considered in the algorithm used to reduce the data from a bath sample. This matrix effect was not a complication in the alloy measurement, because the gold and copper concentrations are dependent variables.

\section{Equipment}

This work was done using an energy dispersive $\mathrm{X}$-ray fluorescent system consisting of a radioactive source, a cryogenic solidstate detector, a multi-channel pulse height analyzer, and a programmable calculator to read and analyze the data. The equipment is shown in Figure 1 and the heated sample chamber is shown in Figure 2 .

The radioactive source is cadmium 109 on a silver backing. The source activity was about $230 \mathrm{MBq}(6.3 \mathrm{mCi})$ at the time the calibration data was collected. Cadmium 109 decays by means of electron capture to an isomer of silver 109. The silver isomer decays with a half-life of 40 seconds to stable silver 109 with emission of an $87.7 \mathrm{keV}$ gama. The $87.7 \mathrm{keV}$ gama produces 22.2 keV X-rays from the fluorescence of silver atoms in the backing on the cadmium source. The silver $22.2 \mathrm{keV} X-r a y s$ are primarily responsible for the excitation of the gold and copper in the sample being analyzed.

A detector system based on a lithium-drifted silicon diode detector was used. Both the Si(Li) diode and the field-effect transistor (FET) first stage of a preamplifier are mounted in a cryostat and are operated at liquid nitrogen temperature for best performance. The Si(Li) diode detector is located in vacuum behind a $13-\mu \mathrm{m}$ beryllium entrance window. The X-rays pass through the beryllium window on the cryostat end cap to reach the sensitive volume of the Si(Li) diode detector.

Voltage pulses from the detector system are analyzed by a pulse height analyzer. The incoming analog voltage pulses are digitized; the digital value corresponds to a channel number. Each voltage pulse results in the addition of one count to the appropriate channel. The multichannel analyzer can store up to $10^{6}-1$ counts in any channel. The resulting count versus channel or intensity versus energy spectrum is displayed on the CRT and then read by 


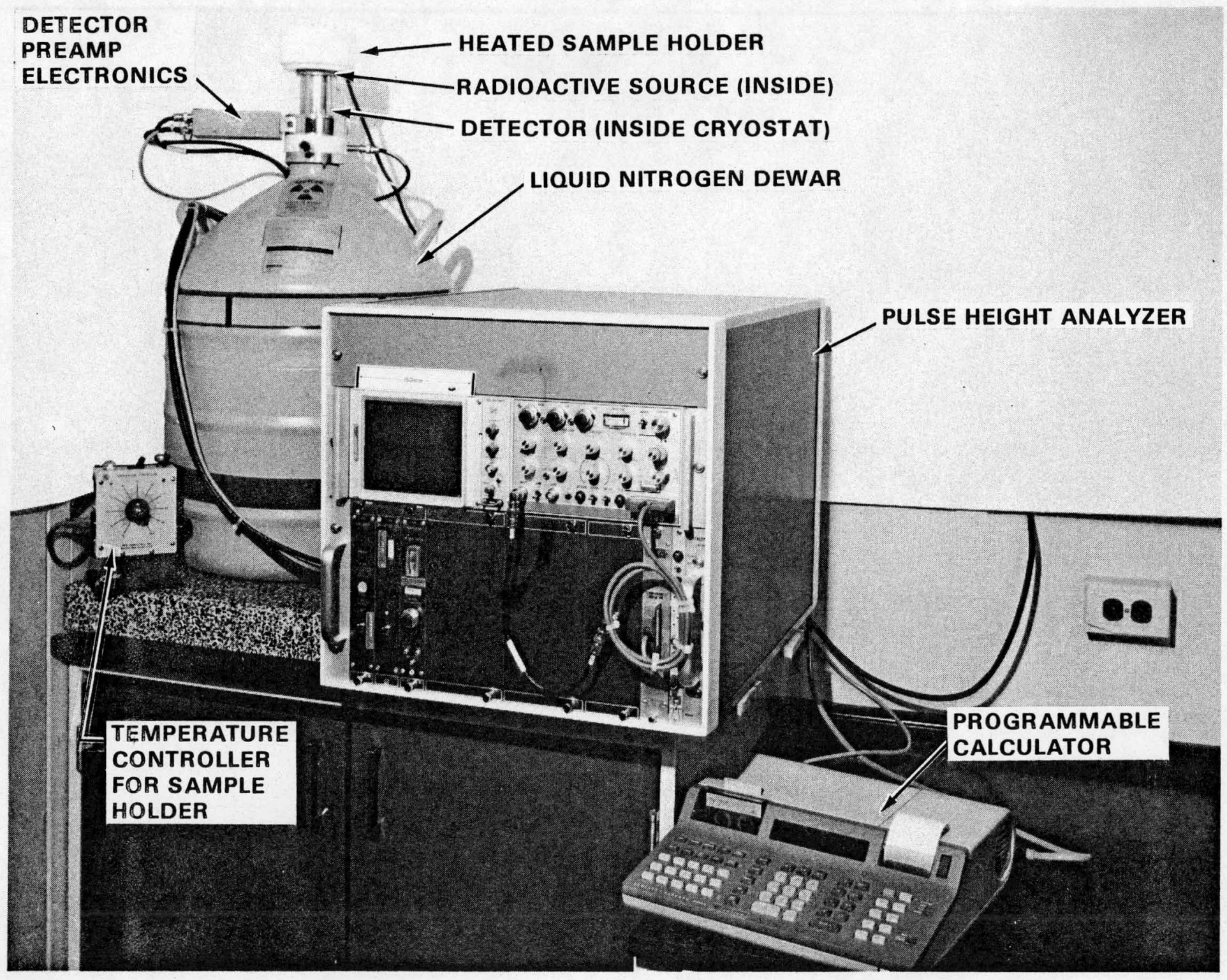

Figure 1. X-Ray Analysis Equipment 


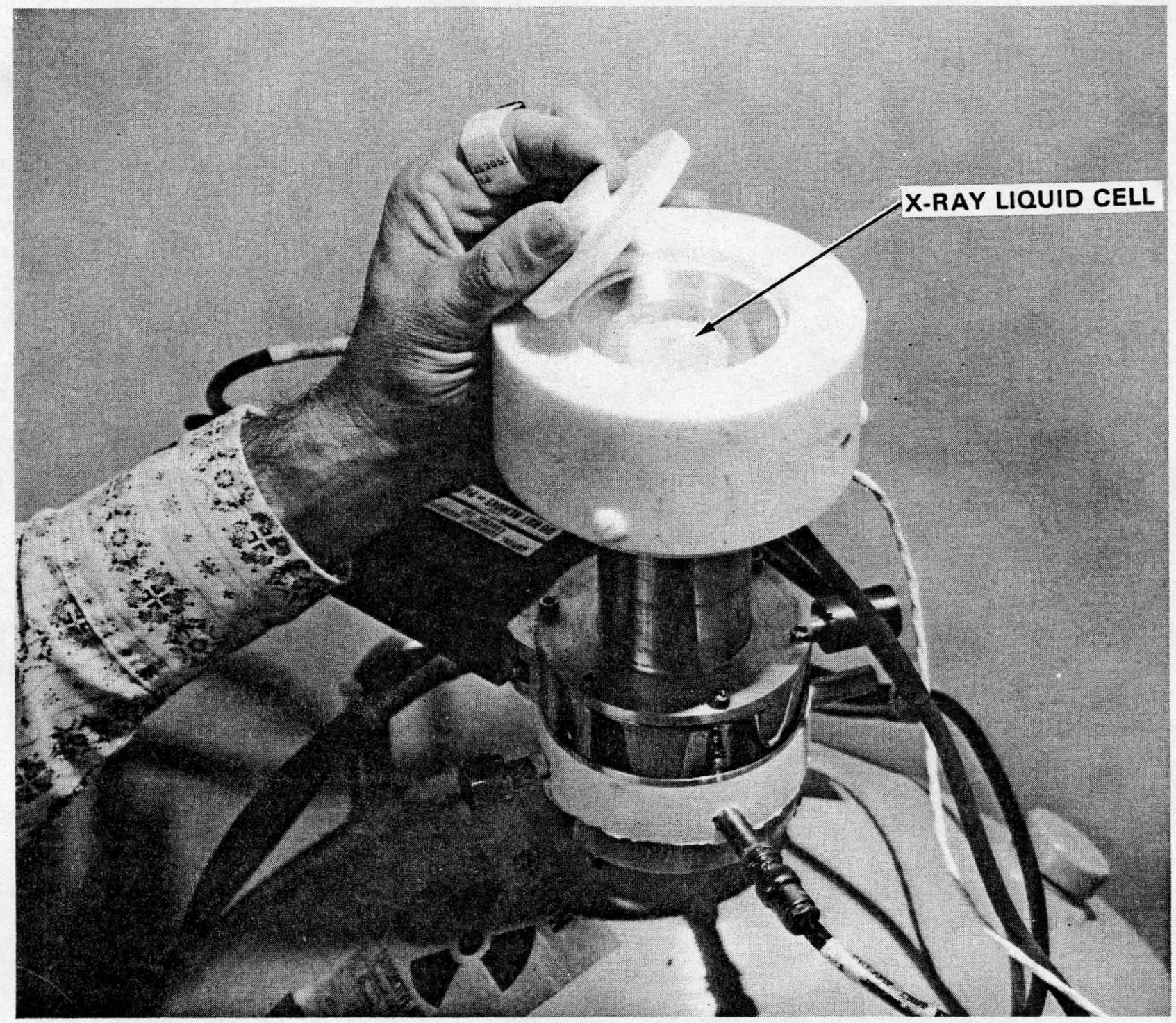

Figure 2. Heated Sample Holder

the desk calculator. After a preset count time, the data from the memory of the multichannel analyzer are read from the analyzer by the desk calculator. The calculator reduces the raw data based on the previously stored calbration data and prints the results.

Calibration Standards, Make-Up

Twenty-one 100-mL bath samples with known gold and copper concentrations were made-up for standards. All constituents of the 
bath were held constant with the exception of the gold or the copper concentration. The gold concentration was varied from 22 to $38 \mathrm{~g} / \mathrm{L}$, while the copper was held near the nominal bath concentrations of $5.3 \mathrm{~g} / \mathrm{L}$. The copper concentration was varied from 3.8 to $6.4 \mathrm{~g} / \mathrm{L}$, while the gold concentration was held near the nominal value of $30 \mathrm{~g} / \mathrm{L}$.

The samples were constructed by first preparing a background solution of boric acid and potassium citrate at twice the plating bath concentration. The $2 \mathrm{X}$ background solution contained $30 \mathrm{~g} / \mathrm{L}$ boric acid and $100 \mathrm{~g} / \mathrm{L}$ potassium citrate. A $50-\mathrm{mL}$ sample of background solution was added to each of the twenty-one 100-mL volumetric flasks. Carefully assayed gold salts and copper concentrate were measured and the appropriate amounts added to each flask. The solution yolume in each flask was then raised to the $100-\mathrm{mL}$ level.

The standards were carefully prepared to obtain accurate gold and copper metal concentrations. The potassium-gold cyanide salts, which contained some potassium cyanide, were vacuum dried. Three separate analyses were performed to determine the gold concentration. Seven measurements were made to determine the copper concentrations in the copper DTPA concentrate. The results of these checks are shown in Table 1 . The average values shown in Table 1 were used. to determine the amount of gold salts and copper concentrate that was added to the calibration sample. Before collecting the $X$-ray spectrum from the calibration samples, it was necessary to determine how much bath solution would be required for an analysis.

\section{Infinite Depth Determination}

An estimate of the infinite thickness was first made by using data obtained from the previous $X-r a y$ fluorescent alloy measurements. It was shown that there was no detectable contribution below $15 \mu \mathrm{m}$ of alloy deposit, and that most of the return was from a layer one-fifth of this thickness. I The density of the five-weight-percent alloy is $18.1 \mathrm{~g} / \mathrm{cm}^{3}$ or $6.12 \mathrm{x} 10^{22} \mathrm{atoms} / \mathrm{cm}^{3}$ for an average distance between atoms of $2.54 \times 10^{-8} \mathrm{~cm}$. Therefore, an infinite depth of 15: $\mu \mathrm{m}$ corresponds to penetration through 5.9 $x 104$ atoms. In the plating bath, the gold plus copper density is $0.035 \mathrm{~g} / \mathrm{cm}^{3}$ or approximately one-five hundredth the density of gold and copper atoms in the alloy: Neglecting the absorption of the water and other low. $Z$ elements in the plating bath, the maximum for the infinite depth of the plating bath would be 500 times that of the alloy or $7.5 \mathrm{~mm}$. The cross-sectional area of the cylindrical sample holder is $4.92 \mathrm{~cm}^{2}$. Therefore, $3.69 \mathrm{~mL}$ of solution is required to obtain a depth of $7.5 \mathrm{~mm}$.

An experimental determination of the solution's depth required for an infinite thickness was also made. Twenty bath samples 
Table 1. Analysis of Gold Salts and Copper Concentrate

\begin{tabular}{|c|c|c|c|}
\hline \multicolumn{2}{|l|}{ Gold Salts } & \multicolumn{2}{|c|}{ Copper Concentrate } \\
\hline $\begin{array}{l}\text { Assay } \\
\text { Number }\end{array}$ & $\begin{array}{l}\text { Results } \\
\text { (Percent Gold) }\end{array}$ & $\begin{array}{l}\text { Assay } \\
\text { Number }\end{array}$ & $\begin{array}{l}\text { Results } \\
(\mathrm{g} / \mathrm{L})\end{array}$ \\
\hline $\begin{array}{l}1 \\
2 \\
3\end{array}$ & $\begin{array}{l}67.21 \\
67.17 \\
67.17\end{array}$ & $\begin{array}{l}1 \\
2 \\
3 \\
4 \\
5 \\
6 \\
7 \\
8\end{array}$ & $\begin{array}{l}47.42 \\
47.30 \\
47.26 \\
47.26 \\
47.42 \\
47.30 \\
47.26 \\
47.26\end{array}$ \\
\hline Average & 67.183 & Average & 47.31 \\
\hline $\begin{array}{l}\text { Standard } \\
\text { Deviation }\end{array}$ & 0.023 & $\begin{array}{l}\text { Standard } \\
\text { Deviation }\end{array}$ & 0.07 \\
\hline
\end{tabular}

ranging from 0.4 to $5.5 \mathrm{~mL}$ were tested. The results showing gold and copper intensity as a function of solution volume are plotted in Figure 3. The graph shows the $X-r a y$ intensity from the sample is maximized for depth greater than about $4 \mathrm{~mm}$. This is in good agreement with the outside limit of $7.5 \mathrm{~mm}$ calculated above.

A sample volume of $3 \mathrm{~mL}$ was selected to provide an infinite depth. A 3-mL sample results in a depth of about $6 \mathrm{~mm}$.

The agreement between the rough theoretical calculation and the experimental measurement of infinite depth is encouraging, because it indicates that the low $Z$ constituents of the bath do not have a major influence on the X-ray response of the samples. The normal minor changes in the bath chemistry should not significantly affect the measurement of gold and copper concentrations.

Collection of Calibration Data

The overall electronic calibration of the X-ray fluorescent system is first checked to ensure the appropriate X-ray energy/channel number relationship exists. ${ }^{1}$ The software used to read the intensity of the fluorescent $X$-rays searches a region of the spectrum which should contain the copper $K \alpha$ peak. A 15-channelwide window is moved over the region of interest until the sum of the counts in the window is maximized. The 15-channel sum is background adjusted and used to represent the copper X-ray intensity. Likewise, the gold intensity is determined from the L $\alpha$ fluorescence. The software search for the peak eliminates the need for precise energy calibration of systems. 


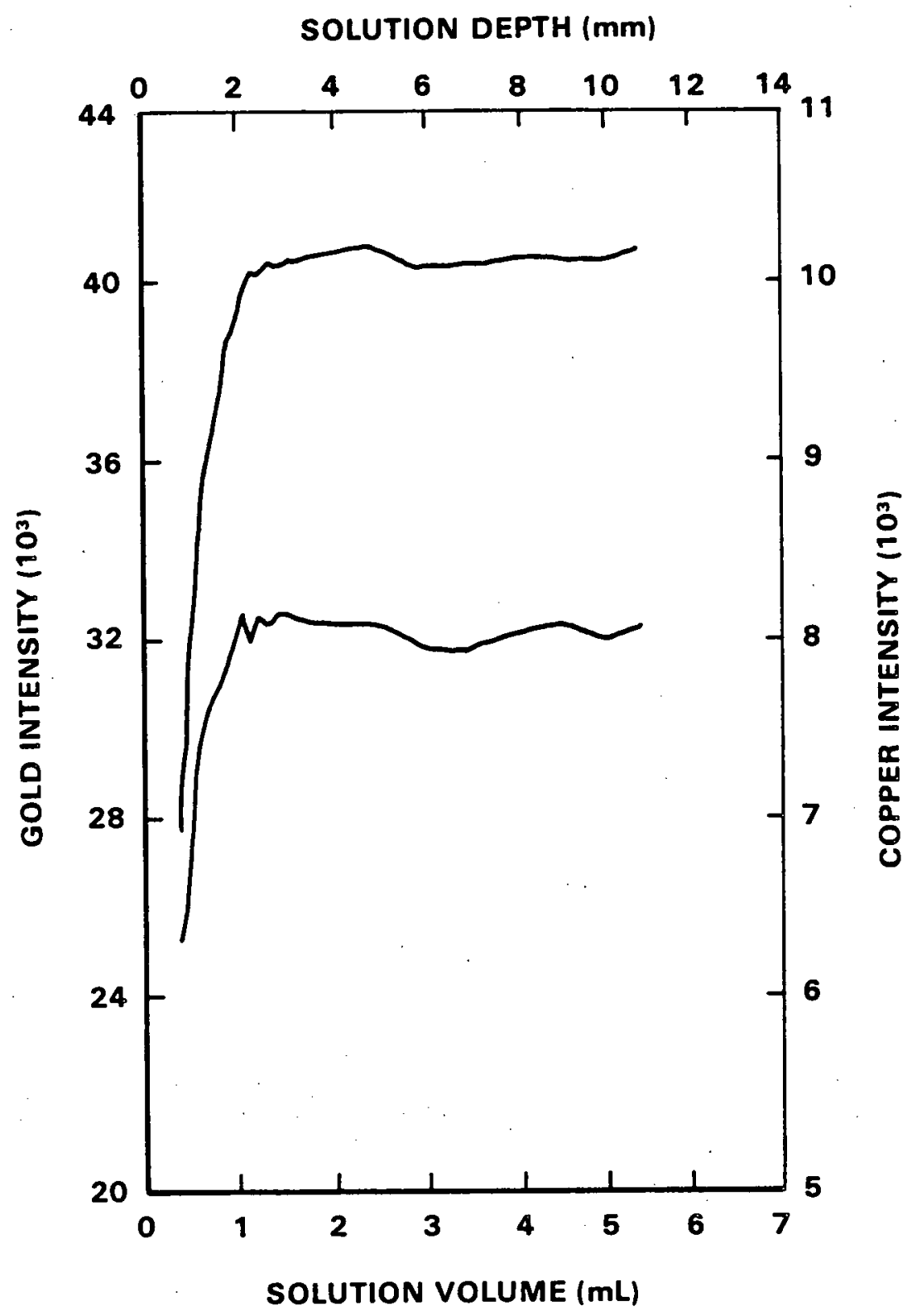

Figure 3, Infinite Depth Determination

The 100-mL samples were heated to redissolve all salts and then stirred to provide a homogeneous sample. Approximately. $3 \mathrm{~mL}$ of the sample to be analyzed was pipetted into a disposable X-ray liquid cell (a $25-\mathrm{mm}$-diameter polyethylene ring with a $635-\mu \mathrm{m}-$ thick Mylar film stretched across the bottom 2. The liquid cell was then placed in the heated sample chamber which had previously been adjusted to approximately $60^{\circ} \mathrm{C}$. The heated sample holder centers the liquid cell containing the bath sample above the radioactive source and detector. A 500-second live-time count is used for each of the calibration bath samples. Table 2 lists the 
Table 2. Measured Intensities and Calculated Concentrations

\begin{tabular}{|c|c|c|c|c|c|c|c|c|}
\hline \multirow[b]{3}{*}{$\begin{array}{l}\text { Sample } \\
\text { Number }\end{array}$} & \multirow{2}{*}{\multicolumn{2}{|c|}{ Intensity }} & \multirow{2}{*}{\multicolumn{2}{|c|}{$\begin{array}{l}\text { Actual } \\
\text { Concentration }\end{array}$}} & \multicolumn{4}{|c|}{ Calculation Method } \\
\hline & & & & & \multicolumn{2}{|c|}{ Iterative } & \multicolumn{2}{|l|}{ Surface } \\
\hline & $\begin{array}{l}\text { Gold } \\
\text { (A) }\end{array}$ & $\begin{array}{l}\text { Copper } \\
\text { (B) }\end{array}$ & $\begin{array}{l}\text { Gold } \\
\text { (C) }\end{array}$ & $\begin{array}{l}\text { Copper } \\
\text { (D) }\end{array}$ & $\begin{array}{l}\text { Gold } \\
(E)\end{array}$ & $\begin{array}{l}\text { Copper } \\
\text { (F) }\end{array}$ & $\begin{array}{l}\text { Gold } \\
(G)\end{array}$ & $\begin{array}{l}\text { Copper } \\
\text { (H) }\end{array}$ \\
\hline $\begin{array}{l}1 \\
2 \\
3 \\
4 \\
5\end{array}$ & $\begin{array}{l}165313.0 \\
176027.0 \\
185921.0 \\
194303.0 \\
198697.0\end{array}$ & $\begin{array}{l}42796.0 \\
42417.0 \\
41578.0 \\
41233.0 \\
39907.0\end{array}$ & $\begin{array}{l}22.005 \\
24.002 \\
25.999 \\
28.004 \\
28.999\end{array}$ & $\begin{array}{l}5.215 \\
5.215 \\
5.215 \\
5.215 \\
5.215\end{array}$ & $\begin{array}{l}21.905 \\
23.980 \\
26.045 \\
27.983 \\
28.910\end{array}$ & $\begin{array}{l}5.201 \\
5.241 \\
5.223 \\
5.268 \\
5.131\end{array}$ & $\begin{array}{l}21.662 \\
23.883 \\
26.008 \\
28.005 \\
28.915\end{array}$ & $\begin{array}{l}5.020 \\
5.116 \\
5.132 \\
5.220 \\
5.080\end{array}$ \\
\hline $\begin{array}{l}6 \\
7 \\
8 \\
9 \\
10\end{array}$ & $\begin{array}{l}205848.0 \\
210562.0 \\
217388.0 \\
225272.0 \\
231327.0\end{array}$ & $\begin{array}{l}39698.0 \\
39299.0 \\
38632.0 \\
38315.0 \\
36810.0\end{array}$ & $\begin{array}{l}30.998 \\
31.999 \\
34.004 \\
36.003 \\
38.000\end{array}$ & $\begin{array}{l}5.215 \\
5.215 \\
5.215 \\
5.215 \\
5.215\end{array}$ & $\begin{array}{l}30.739 \\
31.968 \\
33.812 \\
36.149 \\
37.780\end{array}$ & $\begin{array}{l}5.194 \\
5.202 \\
5.206 \\
5.295 \\
5.168\end{array}$ & $\begin{array}{l}30.784 \\
32.024 \\
33.880 \\
36.177 \\
37.887\end{array}$ & $\begin{array}{l}5.181 \\
5.209 \\
5.241 \\
5.358 \\
5.265\end{array}$ \\
\hline $\begin{array}{l}11 \\
12 \\
13 \\
14 \\
15\end{array}$ & $\begin{array}{l}207533.0 \\
204838.0 \\
205399.0 \\
203492.0 \\
204582.0\end{array}$ & $\begin{array}{l}29751.0 \\
33020.0 \\
34555.0 \\
36432.0 \\
38399.0\end{array}$ & $\begin{array}{l}30.001 \\
30.000 \\
30.002 \\
30.000 \\
30.000\end{array}$ & $\begin{array}{l}3.792 \\
4.266 \\
4.503 \\
4.741 \\
4.978\end{array}$ & $\begin{array}{l}30.108 \\
29.709 \\
29.999 \\
29.714 \\
30.229\end{array}$ & $\begin{array}{l}3.834 \\
4.242 \\
4.456 \\
4.695 \\
4.987\end{array}$ & $\begin{array}{l}30.275 \\
29.742 \\
30.038 \\
29.718 \\
30.260\end{array}$ & $\begin{array}{l}3.831 \\
4.183 \\
4.402 \\
4.632 \\
4.951\end{array}$ \\
\hline $\begin{array}{l}16 \\
17 \\
18 \\
19 \\
20\end{array}$ & $\begin{array}{l}202593.0 \\
200276.0 \\
200180.0 \\
198334.0 \\
197534.0\end{array}$ & $\begin{array}{l}42038.0 \\
43673.0 \\
45147.0 \\
46568.0 \\
48198.0\end{array}$ & $\begin{array}{l}29.999 \\
30.004 \\
30.000 \\
30.000 \\
30.001\end{array}$ & $\begin{array}{l}5.452 \\
5.689 \\
5.926 \\
6.163 \\
6.400\end{array}$ & $\begin{array}{l}30.214 \\
29.853 \\
30.076 \\
29.830 \\
29.924\end{array}$ & $\begin{array}{l}5.497 \\
5.710 \\
5.936 \\
6.129 \\
6.377\end{array}$ & $\begin{array}{l}30.280 \\
29.965 \\
30.225 \\
30.050 \\
30.212\end{array}$ & $\begin{array}{l}5.509 \\
5.753 \\
6.020 \\
6.256 \\
6.561\end{array}$ \\
\hline 21 & 202228.0 & 40320.0 & 29.999 & 5.215 & 29.869 & 5.236 & 29.906 & 5.213 \\
\hline
\end{tabular}


measured intensities for each sample and the gold and copper concentration in each of the 21 standards. This calibration data was used for two separate data reduction algorithms to convert measured intensity to calculated concentrations. The two methods were tested using the intensities measured on the calibration samples. The absolute and percent errors for both methods are listed in Table 3 .

\section{Algorithm for Analysis of Unknowns}

The first step in the analysis of an unknown gold-copper bath sample is to adjust the background corrected gold and copper $X-r a y$ intensity to compensate for source decay and for count time if different than the 500-second count time used for the calibration samples. The analysis program automatically adjusts the intensities to correct for the exponential decay of the source based on a 453-day half-life of the cadmium 109 and the elapsed time between the collection of the calibration data and analysis of the unknown. The analysis program also reads the actual count time from the pulse height analyzer and adjusts the intensity by a factor equal. to 500 seconds divided by the actual count time. A typical count time of 100 seconds results in the measured intensity being multiplied by 5 in addition to the increase to compensate for source decay. After these corrections for background, source decay, and count time, the adjusted gold and copper intensity from the unknown are directly comparable to the background corrected intensities measured on the bath calibration samples.

Iterative Method

Two different algorithms were used to reduce the adjusted intensities to gold and copper concentrations. An iterative method using four 2-dimensional equations and a direct method using two 3-dimensional equations were programmed and used. The intensities measured on the 21 bath calibration samples were used to calculate the calibration equations for both methods. Comparable results were obtained from both.

The four equations used for the iterative method are plotted in Figures $4,5,6$, and 7 . The data points and the least squares best fit of a second degree polynomial are shown. The data points on Figure 4 can be found in Table 1. These points are those measured on the bath samples having constant copper concentration and a range of gold concentrations. Similarly, Figure 5 was constructed from data from samples having a range of copper concentrations. If it were not for the fact that the gold concentration affects the copper intensity and vice versa, these two curves would be sufficient for the analysis of an unknown. Figure 6 shows that the gold concentration does affect the copper intensity. The normalized copper intensity is plotted with a 
Table 3. Absolute and Relative Percent Error

\begin{tabular}{|c|c|c|c|c|}
\hline \multirow[b]{2}{*}{$\begin{array}{l}\text { Sample } \\
\text { Number. }\end{array}$} & \multicolumn{2}{|l|}{ Gold } & \multicolumn{2}{|l|}{ Copper. } \\
\hline & $\begin{array}{l}\text { Absolute } \\
(\mathrm{g} / \mathrm{L})\end{array}$ & $\begin{array}{l}\text { Relative } \\
\text { Percent }\end{array}$ & $\begin{array}{l}\text { Absolute } \\
(g / L)\end{array}$ & $\begin{array}{l}\text { Relative } \\
\text { Percent }\end{array}$ \\
\hline \multicolumn{5}{|c|}{ Iterative Method } \\
\hline & $E-C$ & $\frac{|E-C|}{C} \times 100$ & $D-B$ & $\frac{\mid D-B}{B} \mid \times 100$ \\
\hline $\begin{array}{l}1 \\
2 \\
3 \\
4 \\
5\end{array}$ & $\begin{array}{r}-0.1001 \\
-0.0225 \\
0.0463 \\
-0.0216 \\
-0.0895\end{array}$ & $\begin{array}{l}0.454 \\
0.094 \\
0.178 \\
0.077 \\
0.308\end{array}$ & $\begin{array}{r}-0.0134 \\
0.0263 \\
0.0079 \\
0.0536 \\
-0.0834\end{array}$ & $\begin{array}{l}0.257 \\
0.505 \\
0.152 \\
1.028 \\
1.599\end{array}$ \\
\hline $\begin{array}{l}6 \\
7 \\
8 \\
9 \\
10\end{array}$ & $\begin{array}{r}-0.2588 \\
-0.0312 \\
-0.1920 \\
0.1460 \\
-0.2202\end{array}$ & $\begin{array}{l}0.834 \\
0.097 \\
0.564 \\
0.405 \\
0.579\end{array}$ & $\begin{array}{r}-0.0208 \\
-0.0129 \\
-0.0081 \\
0.0803 \\
-0.0467\end{array}$ & $\begin{array}{l}0.399 \\
0.248 \\
0.156 \\
1.540 \\
0.896\end{array}$ \\
\hline $\begin{array}{l}11 \\
12 \\
13 \\
14 \\
15\end{array}$ & $\begin{array}{r}0.1068 \\
-0.2902 \\
-0.0025 \\
-0.2862 \\
0.2293\end{array}$ & $\begin{array}{l}0.356 \\
0.967 \\
0.008 \\
0.954 \\
0.764\end{array}$ & $\begin{array}{r}0.0416 \\
-0.0246 \\
-0.0474 \\
-0.0452 \\
0.0099\end{array}$ & $\begin{array}{l}1.097 \\
0.578 \\
1.053 \\
0.955 \\
0.198\end{array}$ \\
\hline $\begin{array}{l}16 \\
17 \\
18 \\
19 \\
20\end{array}$ & $\begin{array}{r}0.2152 \\
-0.1506 \\
0.0764 \\
-0.1696 \\
-0.0766\end{array}$ & $\begin{array}{l}0.717 \\
0.502 \\
0.254 \\
0.565 \\
0.255\end{array}$ & $\begin{array}{r}0.0450 \\
0.0215 \\
0.0107 \\
-0.0333 \\
-0.0232\end{array}$ & $\begin{array}{l}0.825 \\
0.378 \\
0.181 \\
0.541 \\
0.363\end{array}$ \\
\hline 21 & -0.1303 & 0.434 & 0.0216 & 0.414 \\
\hline Average & -0.0582 & 0.446 & -0.0019 & 0.636 \\
\hline Absolute & 0.1363 & 0.446 & 0.0322 & 0.636 \\
\hline $\begin{array}{l}\text { Standard } \\
\text { Deviation }\end{array}$ & 0.1551 & 0.287 & 0.0396 & 0.442 \\
\hline
\end{tabular}


Table 3 Continued. Absolute and Relative Percent Error

\begin{tabular}{|c|c|c|c|c|}
\hline \multirow[b]{2}{*}{$\begin{array}{l}\text { Sample } \\
\text { Number: }\end{array}$} & \multicolumn{2}{|l|}{ Gold } & \multicolumn{2}{|l|}{ Copper } \\
\hline & $\begin{array}{l}\text { Absolute } \\
(\mathrm{g} / \mathrm{L})\end{array}$ & $\begin{array}{l}\text { Relative } \\
\text { Percent }\end{array}$ & $\begin{array}{l}\text { Absolute } \\
(g / L)\end{array}$ & $\begin{array}{l}\text { Relative } \\
\text { Percent }\end{array}$ \\
\hline \multicolumn{5}{|c|}{ Surface Method } \\
\hline & $G-C$ & $\frac{|\mathrm{G}-\mathrm{C}|}{\mathrm{C}} \times 100$ & $\mathrm{H}-\mathrm{B}$ & $\frac{\mid H-B}{B} \mid \times 100$ \\
\hline $\begin{array}{l}1 \\
2 \\
3 \\
4 \\
5\end{array}$ & $\begin{array}{r}-0.3438 \\
-0.1192 \\
0.0087 \\
0.0003 \\
-0.0843\end{array}$ & $\begin{array}{l}1.562 \\
0.497 \\
0.033 \\
0.001 \\
0.290\end{array}$ & $\begin{array}{r}-0.1949 \\
-0.0988 \\
-0.0822 \\
0.0051 \\
-0.1349\end{array}$ & $\begin{array}{l}3.737 \\
1.895 \\
1.576 \\
0.097 \\
2.587\end{array}$ \\
\hline $\begin{array}{l}6 \\
7 \\
8 \\
9 \\
10\end{array}$ & $\begin{array}{r}-0.2141 \\
0.0255 \\
-0.1241 \\
0.1738 \\
-0.1131\end{array}$ & $\begin{array}{l}0.690 \\
0.079 \\
0.365 \\
0.482 \\
0.297\end{array}$ & $\begin{array}{r}-0.0339 \\
-0.0060 \\
0.0268 \\
0.1435 \\
0.0499\end{array}$ & $\begin{array}{l}0.651 \\
0.115 \\
0.515 \\
2.752 \\
0.958\end{array}$ \\
\hline $\begin{array}{l}11 \\
12 \\
13 \\
14 \\
15\end{array}$ & $\begin{array}{r}0.2739 \\
-0.2572 \\
0.0359 \\
-0.2824 \\
0.2604\end{array}$ & $\begin{array}{l}0.913 \\
0.857 \\
0.119 \\
0.941 \\
0.868\end{array}$ & $\begin{array}{r}0.0387 \\
-0.0830 \\
-0.1019 \\
-0.1083 \\
-0.0270\end{array}$ & $\begin{array}{l}1.021 \\
1.946 \\
2.263 \\
2.285 \\
0.542\end{array}$ \\
\hline $\begin{array}{l}16 \\
17 \\
18 \\
19 \\
20\end{array}$ & $\begin{array}{r}0.2808 \\
-0.0384 \\
0.2257 \\
0.0502 \\
0.2109\end{array}$ & $\begin{array}{l}0.936 \\
0.128 \\
0.752 \\
0.167 \\
0.702\end{array}$ & $\begin{array}{l}0.0569 \\
0.0641 \\
0.0945 \\
0.0929 \\
0.1612\end{array}$ & $\begin{array}{l}1.044 \\
1.127 \\
1.595 \\
1.507 \\
2.519\end{array}$ \\
\hline 21 & -0.0931 & 0.310 & -0.0016 & 0.031 \\
\hline Average & -0.0058 & 0.523 & -0.0066 & 1.465 \\
\hline Absolute & 0.1531 & 0.523 & 0.0765 & 1.465 \\
\hline $\begin{array}{l}\text { Standard } \\
\text { Deviation }\end{array}$ & 0.1898 & 0.403 & 0.0946 & 0.996 \\
\hline
\end{tabular}

*Equations are keyed to the lettered columns of Table 2. 


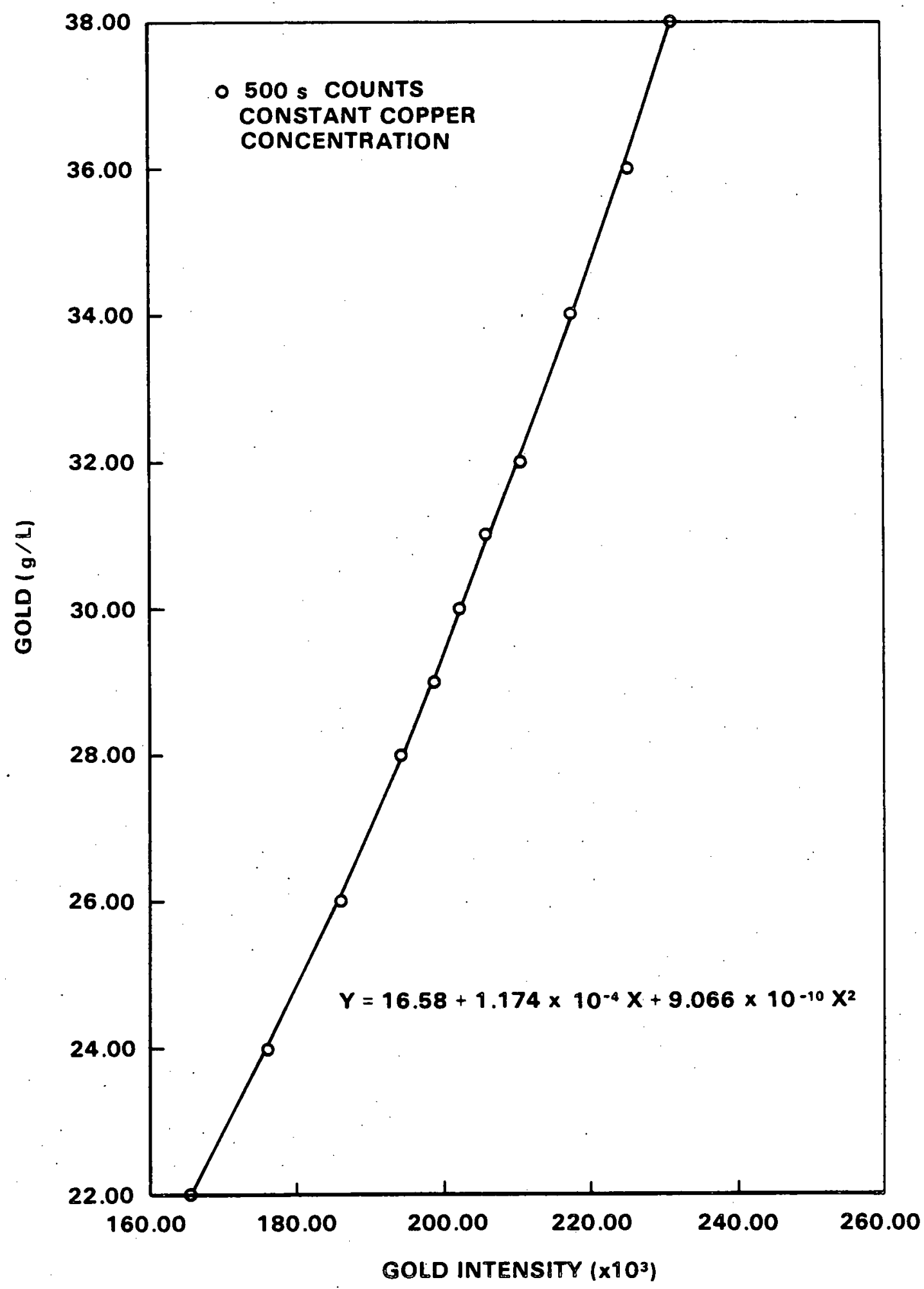

Figure 4. Gold Calibration Curve 


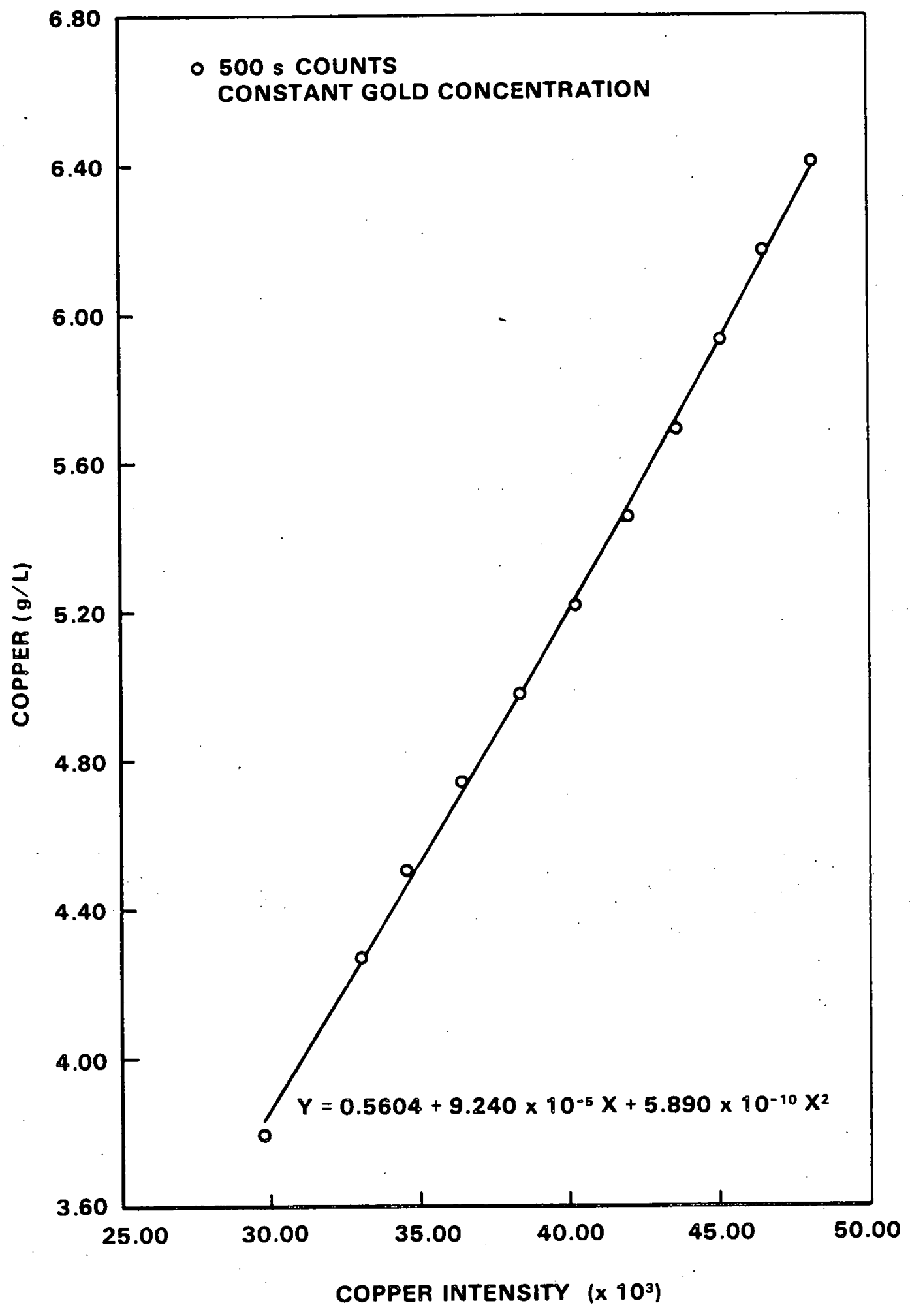

Figure 5. Copper Calibration Curve 


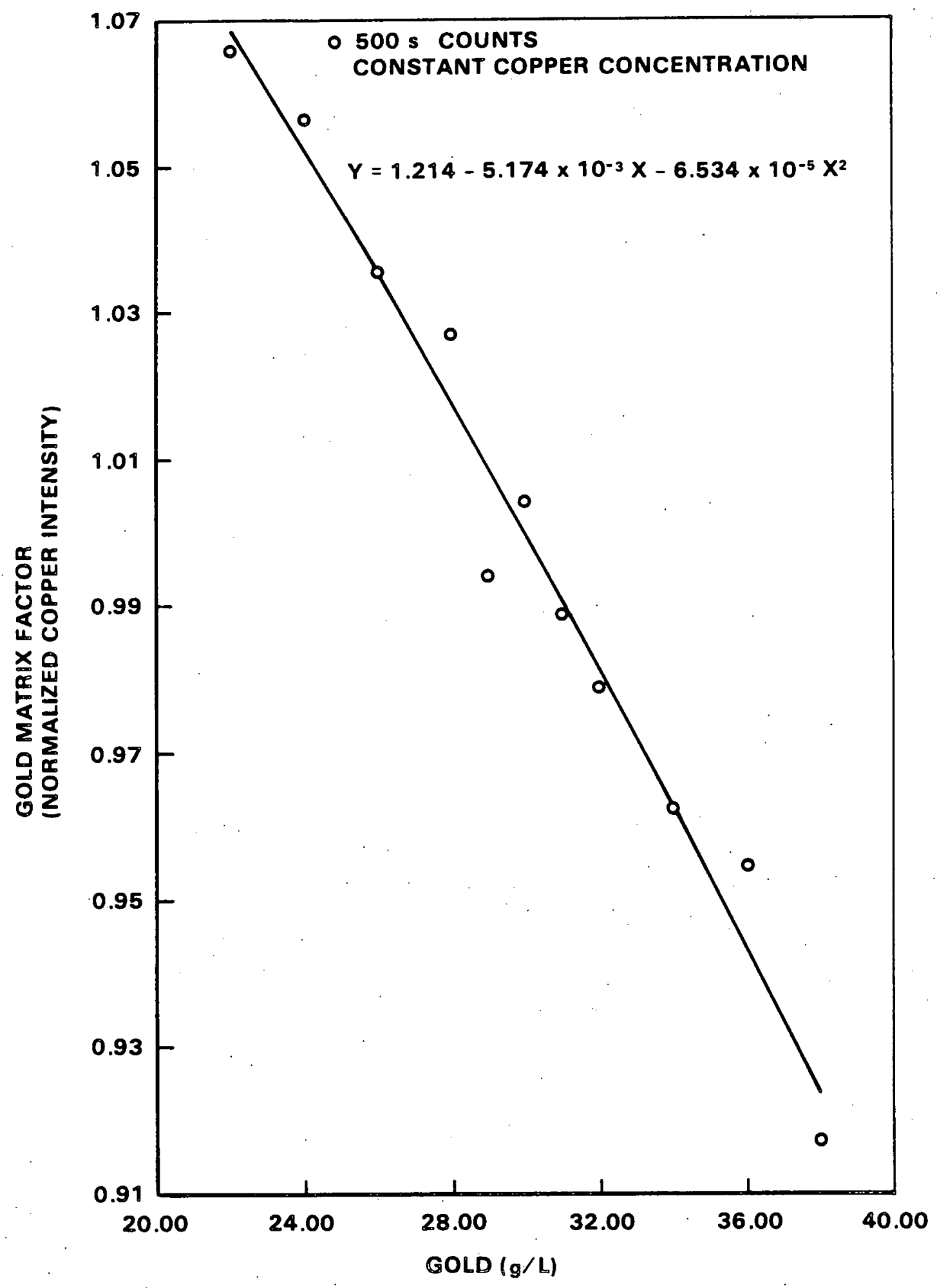

Figure 6. Gold Matrix Effect 


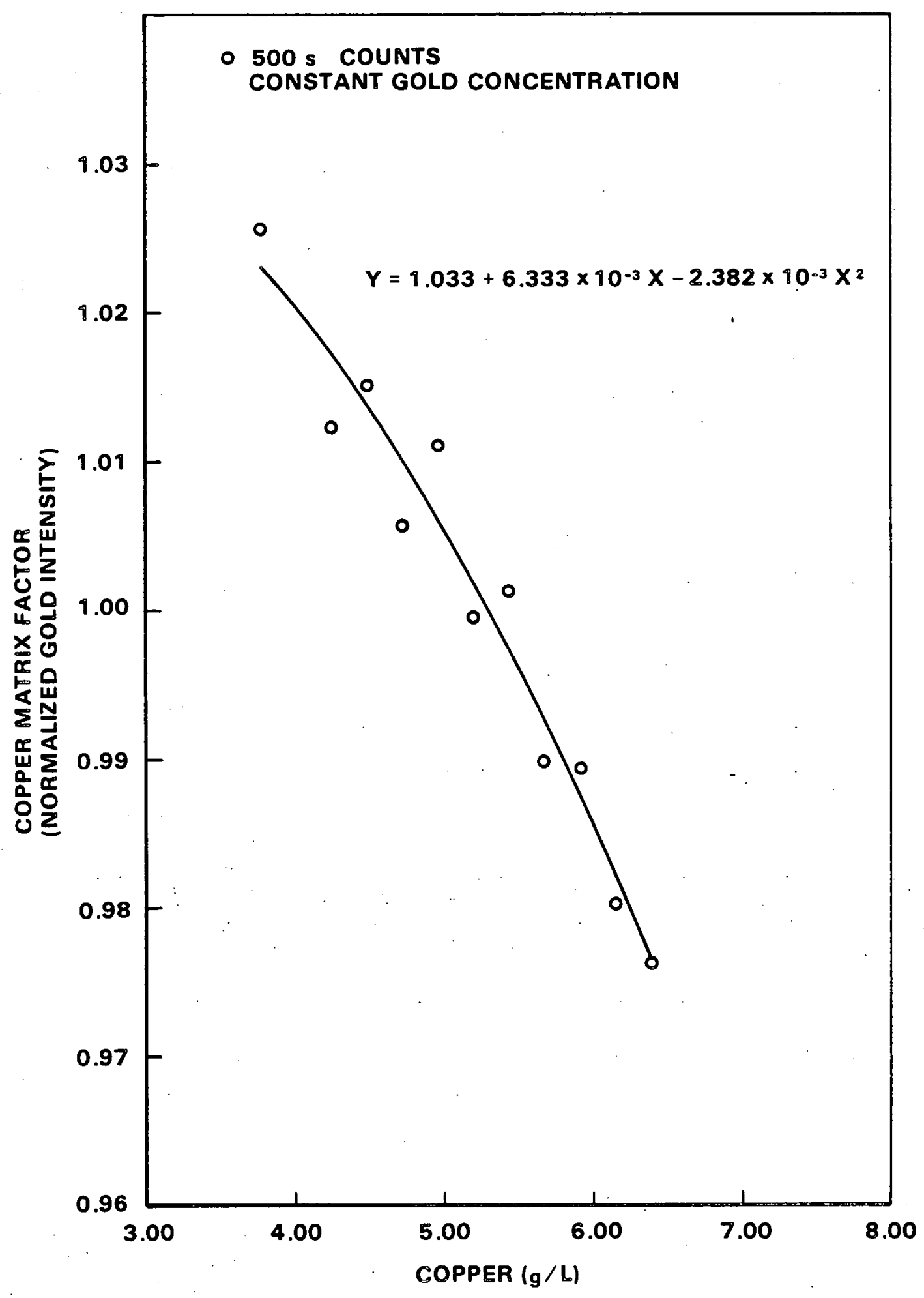

Figure 7. Copper Matrix Effect 
value of 1 assigned to the intensity calculated from the equation in Figure 5 for $5.3 \mathrm{~g} / \mathrm{L}$ copper. Figure 7 is similarly a plot of the normalized gold intensity as a function of the copper concentration. Figure 6 . shows how the copper intensity decreases for increasing gold concentration, even though the copper concentration is held constant. Figure 7 shows how the gold intensities on a. $30 \mathrm{~g} / \mathrm{L}$ gold bath sample are affected by the copper concentration.

A simplified. flow chart of the iterative method used to convert the measured intensity to gold and copper concentration is shown in Figure 8. The measured intensities are used to calculate a first estimate of the gold and copper concentrations from the calibration equations in Figures 4 and 5 . These concentrations are then used to calculate a gold and copper matrix factor which is used to adjust the measured intensities. This adjustment boosts the measured gold intensity if the calculated copper concentration is above the normal value of $5.3 \mathrm{~g} / \mathrm{L}$ and decreases the gold intensity if-the copper is below $5.3 \mathrm{~g} / \mathrm{L}$. The same type of correction is done for the copper intensity. The adjusted intensities are then used to recalculate the concentration. This process is repeated until two successive calculations result in concentrations that differ by less than $0.0001 \mathrm{~g} / \mathrm{L}$ for both gold and copper concentrations. Typically, five or six iterations are required for this calculation of concentrations to converge to this limit. This operation requires a few seconds on the calculator.

\section{Surface Method}

The second method tested used a quadratic least squares approximation in two variables. A surface of the form

$G(G I, C I)=C_{1} \times G I^{2}+C_{2} \times C I^{2}+C_{3} \times G I \times C I+C_{4} G I+C_{5} \times C I+C_{6}$

was fitted to the measured gold concentrations as a function of gold and copper intensity. A similar equation for copper concentrations, C(GI, CI), was fitted to the measured copper concentrations as a function of the gold and copper intensities. The computer-calculated coefficients for the gold calibration surface and the copper calibration surface are shown in Table 4.

Evaluation of an unknown bath sample using these calibration surfaces is relatively simple to program. Only the direct substitution of the adjusted intensity is required and no iterations are needed. A three-dimensional plot of the calibration surfaces are shown in Figure 9.

Tables 2 and 3 compare the two methods. The measured gold and copper intensities from the 21 calibration bath samples are used 


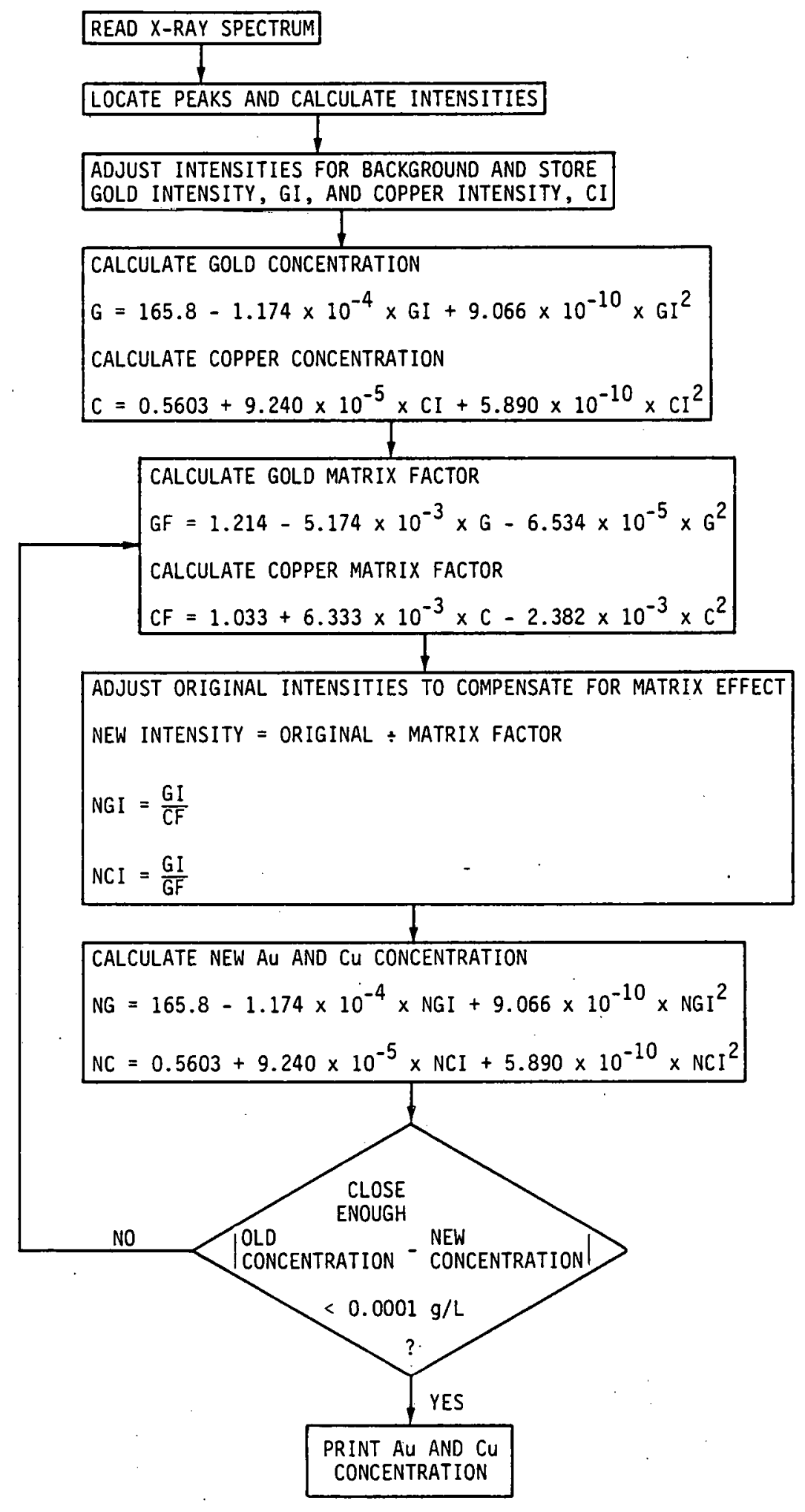

Figure 8. Flow Chart of Iterative Method 
Table 4. Computer-Calculated Coefficients for Gold and Copper Calibration Surface

\begin{tabular}{lll}
\hline $\begin{array}{l}\text { Computer- } \\
\text { Calculated } \\
\text { Coefficient }\end{array}$ & $\begin{array}{l}\text { Gold } \\
\text { Concentration } \\
{[\text { G(GI, CI) }}\end{array}$ & $\begin{array}{l}\text { Copper } \\
\text { Concentration } \\
{[\mathrm{C}(\mathrm{GI}, \mathrm{CI})]}\end{array}$ \\
\hline $\mathrm{C} 1$ & $7.605262 \times 10^{-10}$ & $5.4053222 \times 10^{-11}$ \\
$\mathrm{C} 2$ & $4.5520103 \times 10^{-9}$ & $2.2271867 \times 10^{-9}$ \\
$\mathrm{C} 3$ & $-1.0543000 \times 10^{-9}$ & $-7.5773445 \times 10^{-11}$ \\
$\mathrm{C} 4$ & $3.8995470 \times 10^{-13}$ & $1.7873067 \times 10^{-13}$ \\
$\mathrm{C} 5$ & $1.0337042 \times 10^{-13}$ & $5.4020480 \times 10^{-14}$ \\
$\mathrm{C} 6$ & $4.4710744 \times 10^{-18}$ & $2.0529446 \times 10^{-18}$
\end{tabular}

as inputs to both the iterative method and the surface method. The resulting gold and copper concentrations are listed for both methods. The average error and the standard deviation for gold and copper calculated from the 21 calibration samples by both methods are shown in. Table 3. The iterative method calculated values closer to the values of the calibration samples than did the surface method. The iterative method has, therefore, been selected as the primary algorithm for data reduction.

Accuracy and Precision

Many factors affect the accuracy and precision of this method of analysis of gold/copper plating solutions. An estimate of the effect of the following three factors is summarized in Table 5:

- accuracy of bath standards,

- algorithm for data reduction, and

- statistical counting error.

The accuracy of the bath standards is partly determined by the accuracy of the metal concentration of the gold salt and copper concentrate used to make up the standards. The gold salt was dried and weighed to within $\pm 0.02 \mathrm{mg}$ which would not contribute a significant error. The copper concentrate was pipetted with an accuracy of \pm 0.333 percent and the total solution volume determined in a temperature controlled volumetric flask was \pm 0.1 percent. Assay errors of the gold salt and copper concentrate would contribute a consistent bias. Volume and weight errors would increase the deviation between the measured response and the assigned values of the calibration samples. The calibration curve or data reduction algorithm tends to average out random error from the 


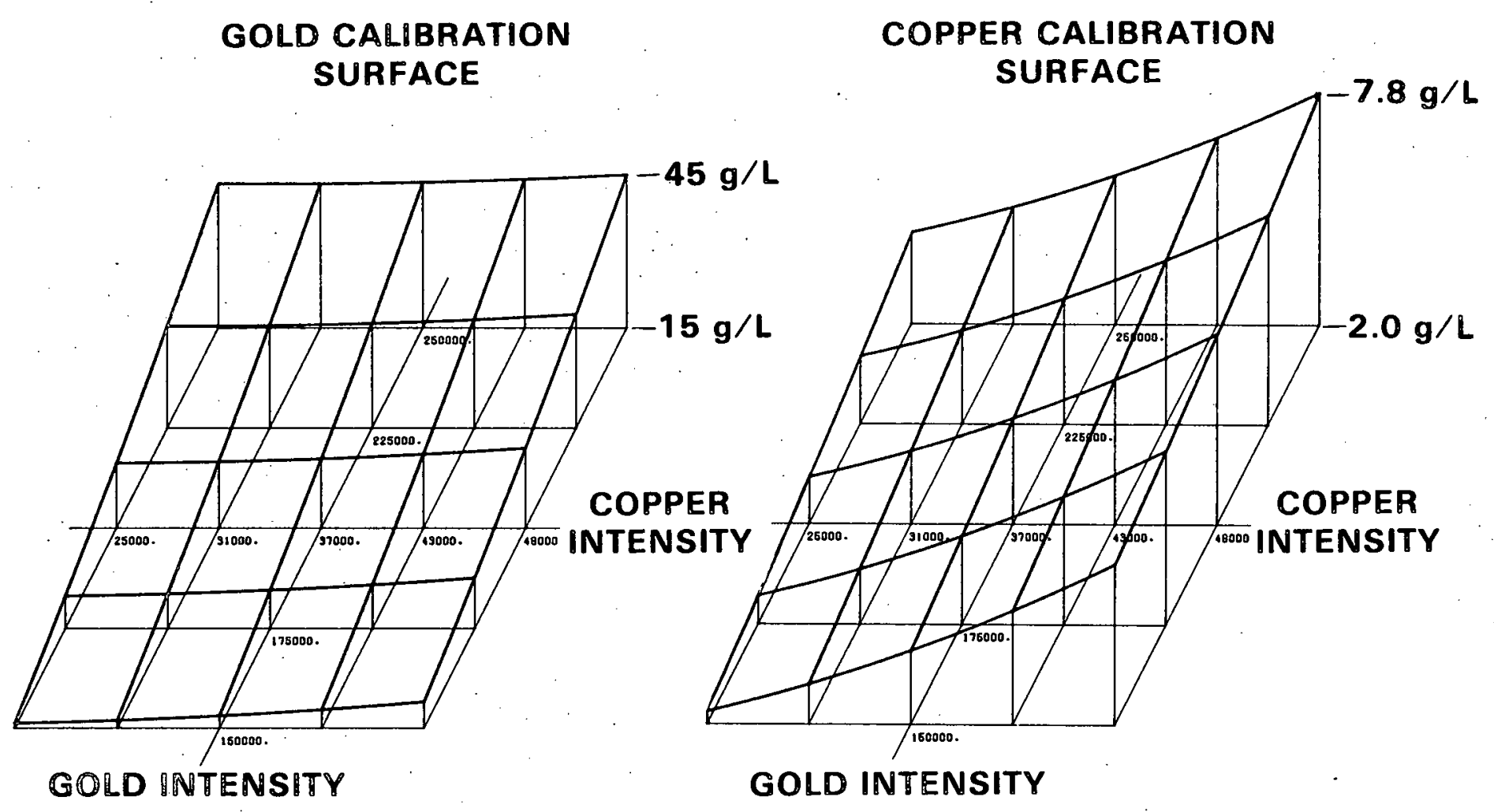

Figure 9. Gold and Copper Calibration Surface 
Table 5. Effect of Count Time and Analysis Method on Accuracy

\begin{tabular}{|c|c|c|c|c|c|c|}
\hline & \multirow{2}{*}{\multicolumn{2}{|c|}{$\begin{array}{l}\text { Standard Deviation } \\
\text { of Adjusted } \\
\text { Intensities }\end{array}$}} & \multicolumn{4}{|c|}{$\begin{array}{l}\text { Standard Deviation Between } \\
\text { Calculated Value and Assigned } \\
\text { Value for Calibration Standards }\end{array}$} \\
\hline & & & \multicolumn{2}{|l|}{ Gold $(g / L)$} & \multicolumn{2}{|c|}{ Copper $(\mathrm{g} / \mathrm{L})$} \\
\hline & $\begin{array}{l}\text { Gold } \\
\text { (Counts) }\end{array}$ & $\begin{array}{l}\text { Copper } \\
\text { (Counts) }\end{array}$ & $\begin{array}{l}\text { Iterative } \\
\text { Method }\end{array}$ & $\begin{array}{l}\text { Surface } \\
\text { Method }\end{array}$ & $\begin{array}{l}\text { Iterative } \\
\text { Method }\end{array}$ & $\begin{array}{l}\text { Surface } \\
\text { Method }\end{array}$ \\
\hline \multicolumn{7}{|c|}{$\begin{array}{l}\text { Processed Data From } \\
21 \text { Batch Calibration } \\
\text { Standards } \\
\text { ( } 500-s \text { counts) }\end{array}$} \\
\hline \multicolumn{7}{|c|}{$\begin{array}{l}\text { Repeat Measurements } \\
\text { on One Sample }\end{array}$} \\
\hline $100-s$ counts & 982 & 384 & 0.248 & 0.253 & 0.054 & 0.059 \\
\hline $500-s$ counts & 416 & 179 & 0.197 & 0.203 & 0.034 & 0.040 \\
\hline
\end{tabular}


21 calibration samples. The standard deviation between the measured value and the assigned values for gold and copper in the 21 calibration samples is shown in Table 5 for both the iterative and surface method. An estimate of the tolerance limits for both methods based on the number of samples and degrees of freedom has been calculated from the 500-second count data from the 21 standards and is shown in Table 6 .

The effect of statistical counting error can be seen in the data taken with different count time. Repeat measurements of the same samples using 100- and 500-second counts are shown in Table 5 . The expected improvement in the standard deviation of the adjusted intensity (inversely proportional to the square root of the count time) can be seen. A less significant improvement in the standard deviation of the calculated concentration is observed. In other words, only a small increase in precision is obtained when the count time is increased from 100 to 500 seconds and an even smaller improvement would be observed with larger count times.

Other sources of error are more difficult to quantify and some will tend to reduce long term accuracy. Source-to-sample geometry changes, beryllium window and detector vacuum degradation, and electronic component drift will decrease accuracy. Periodic calibration against the alloy standard and new liquid bath standards will be necessary.

\section{ACCOMPLISHMENTS}

A system for rapid, precise, simultaneous measurement of gold and copper concentration in an alloy electroplating solution has been established. The new capability resulted from a modification of an existing $X$-ray fluorescence analysis system developed for goldcopper alloy analysis. A heated sample holder was made and software was generated to make the existing system usable for bath analysis. Calibration data was collected from 21 bath calibration samples and two algorithms for data reduction were developed and evaluated. The resulting method can analyze a sample in less than 5 minutes with an accuracy of \pm 1.5 percent.

\section{FUTURE WORK}

Following the initial calibration and checkout of this system, priorities changed and the use of the system was not implemented on a regular basis. Periodic checks of active baths were made and initially agreed well with the standard wet chemistry analysis. Some months after the initial calibrations the X-ray checks resulted in higher concentrations than the standard analysis. Spot checks of nine of the original standards confirmed this trend. The cause of the shift in the calibration curve has not 
Table 6. Estimate of Tolerance Limits*

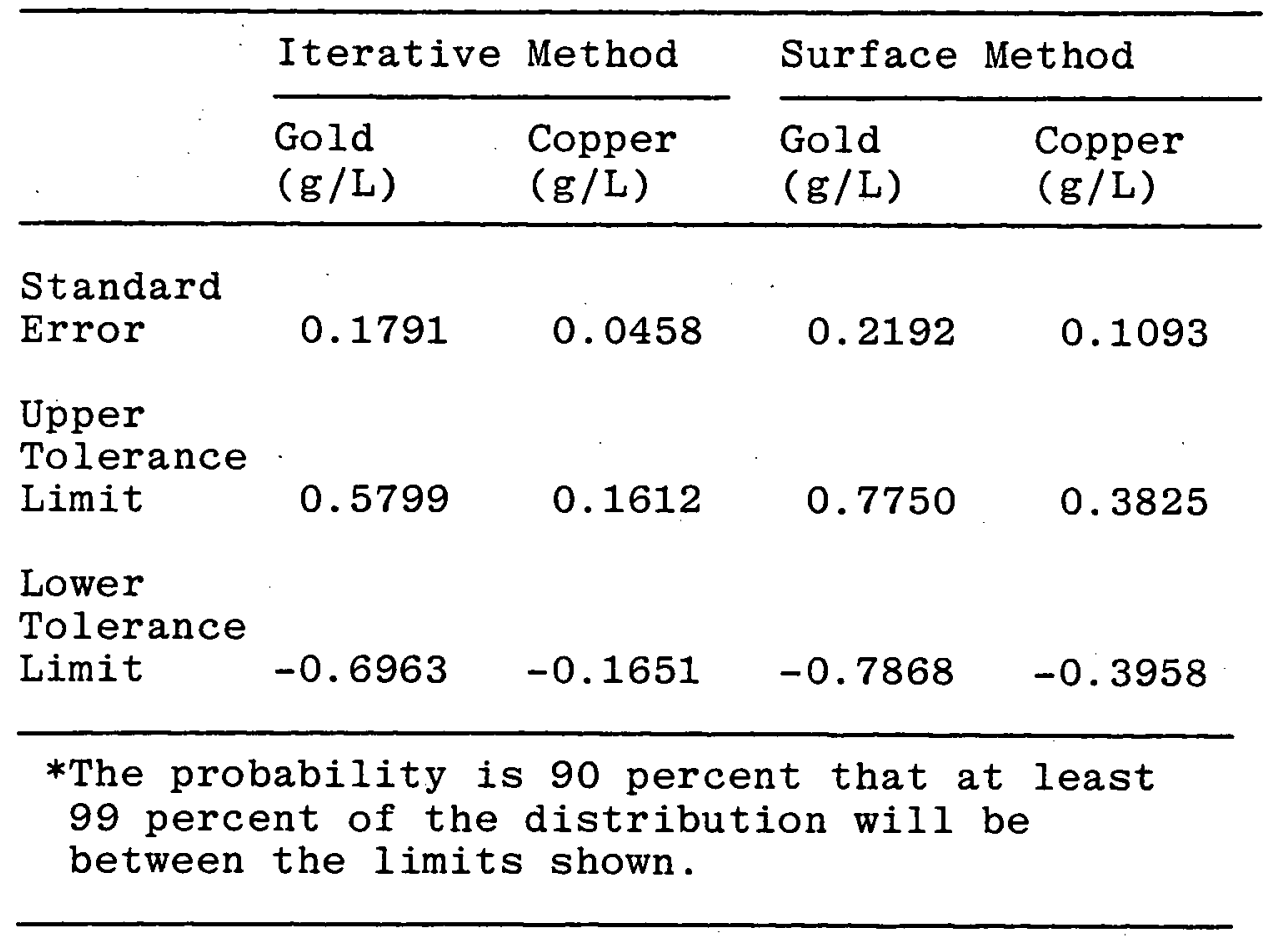

been investigated. The cause of the shift should be found and, if necessary, additional calibration samples should be made and processed to produce new calibration data. 


\section{REFERENCE}

${ }^{1}$ D. M. Starks, Determination of Gold-Copper AZZoy Composition By $X-$ Ray Fluorescence Analysis. (Final Report 2, UNCLASSIFIED. Bendix Kansas City: BDX-613-1716 (Rev..2, September, 1977 (Available from NTIS). 
Appendix

\section{OPERATING PROCEDURE}

Normally, the equipment required for $X-r a y$ fluorescence analysis of a bath sample is left on except for the high voltage supply. The high voltage supply is switched off during liquid nitrogen filling. The system controls for both alloy and bath analysis are identical; therefore, the controls usually do not need to be adjusted. The control settings are listed in Table $\mathrm{A}-1$.

The heated sample chamber and the tape program (RAH1) containing the analysis programs," are unique items to the bath analysis. After removing the cover from the radioactive source, the heated sample chamber is slipped over the source holder. Next, the temperature controller is set to maintain a temperature of 60 to $65^{\circ} \mathrm{C}$ in the chamber.

If not already in place, the tape program is loaded into the calculator. A disposable X-ray liquid cell is then prepared by stretching the $635-\mu \mathrm{m}$ Mylar film across the bottom of the cell and slipping the retainer ring in place. The Mylar film should be smooth and wrinkle free. Wrinkles can change the sample/ source geometry or can cause leaks that could contaminate the beryliium window or source. Geometry changes or contamination will reduce the measurement accuracy.

Approximately. $3 \mathrm{~mL}$ of the bath to be analyzed are pipetted into a liquid cell; then, the liquid cell is placed in the heated sample holder. The desired count time is set on the PHA; typically, 100 seconds is used. The PHA is cleared to zero counts in each channel by momentarily pressing the CLEAR switch. Pushing the ACQUIRE buttons starts the count, which will terminate automatically after the pre-set count time is reached.

While the count is in progress, the program can be loaded by turning the calculator off and then on. (This assumes tape RAHI is in place, and the MODE switch is set to AUTO START.) The AUTO START position loads the program which reduces the data when using the iterative analysis method. The iterative and surface method can be selected by loading and running file 3 on the same tape. The program requires the operator to enter the "day of year" and the "year" for the program to compensate for source decay. The calculator prompts the operator to start I/O. This is accomplished by pushing the I/O button after the selected count time is reached. The I/O button. should be pushed again after the data has been read from the PHA to the calculator. The calculator prints the day and year entered by the operator and the count time it read from the time channels (channel 0 ) of the PHA. A sample of the calculator output is shown in Figure A-1. 
Table A-1. Control Settings

\begin{tabular}{|c|c|c|}
\hline Equipment & Switch or Control & Position \\
\hline \multicolumn{3}{|l|}{ Front Panel Controls } \\
\hline NIM Module & POWER & $\mathrm{ON}$ \\
\hline $\mathrm{LN}_{2}$ Level Monitor & HV ENABLE & ON \\
\hline Detector HV Supply* & $\mathrm{HV}$ & ON \\
\hline Amplifier** & ENERGY CALIBRATION & $\begin{array}{l}9.00 \\
(\mathrm{Gain}=0.090)\end{array}$ \\
\hline Oscilloscope & POWER & ON \\
\hline Pulse Height Analyzer & $\begin{array}{l}\text { GAIN } \\
\text { LLD } \\
\text { ULD } \\
\text { OFFSET } \\
\text { CONVERSION GAIN } \\
\text { UPPER TIME BASE***} \\
\text { LOWER TIME BASE*** } \\
\text { HORIZONTAL } \\
\text { MODE } \\
\text { I/O (Rotary Switch) } \\
\text { AMP } \\
\text { ADD/SUB }\end{array}$ & $\begin{array}{l}0.00 \\
0.50 \\
10.00 \\
0 \\
1024 \\
1 \\
100 \quad(\text { PHA) } \\
\text { FULL } \\
\text { PHA } \\
\text { ALL OUT } \\
\text { OUT } \\
\text { ADD }\end{array}$ \\
\hline Calculator & $\begin{array}{l}\text { PRINTER } \\
\text { RUN / PRGM }\end{array}$ & $\begin{array}{l}\text { NORM } \\
\text { AUTO START }\end{array}$ \\
\hline \multicolumn{3}{|l|}{ Rear Panel Controls } \\
\hline Amplifier & $\begin{array}{l}\text { SHAPING TIME CONSTANT } \\
\text { (S1, S2, S3, and S4) } \\
\text { COARSE GAIN (S3) } \\
\text { INPUT POLARITY (S5) }\end{array}$ & $\begin{array}{l}10 \mu \mathrm{s} \\
200^{-(N e g a t i v e)}\end{array}$ \\
\hline Detector HV Supply & $0-3 \mathrm{kV}$ & 1.00 \\
\hline $\begin{array}{l}\text { *Turn this switch off } \\
\text { **This setting should } \\
444 \text { and the gold La } \\
\text { ***These settings may b }\end{array}$ & $\begin{array}{l}\text { while filling liquid nitrog } \\
\text { position the copper Ka peak } \\
\text { peak at channel } 536 \text { within t } \\
\text { e modified for longer count }\end{array}$ & $\begin{array}{l}\text { gen tank. } \\
\text { at channel } \\
\text { two channels. } \\
\text { times. }\end{array}$ \\
\hline
\end{tabular}




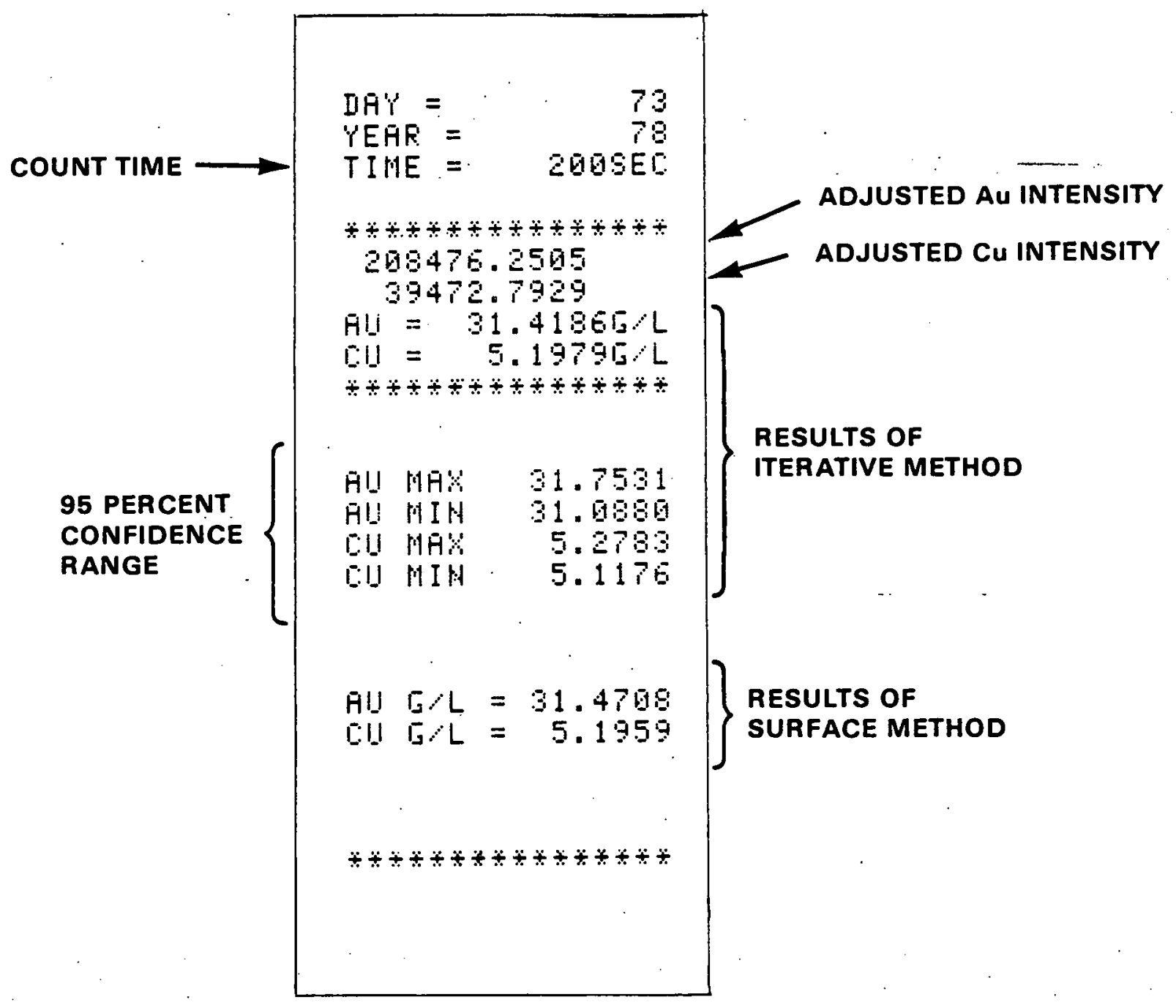

Figure A-1. Sample of Calculator Output

The adjusted gold and copper intensities are printed for reference. In addition to printing the calculated values of gold and copper concentration in grams per liter, the program also estimates a two sigma counting error ( 2 times the square root of the measured intensity) for the gold counts and a two sigma error for the copper. The estimate of gold counting error is added to the measured gold intensity, and the estimate of the copper counting error is subtracted from the measured copper intensity. A value called the maximum gold concentration and the minimum copper concentration is calculated from the new intensities. A similar process is used to calculate the minimum gold concentration and the maximum copper concentration. The four values are the last items printed. The process of simultaneously doing a two sigma adjustment on the gold and copper intensities results in calculated maximum and minimum concentrations that exceed the two sigma error band caused by interaction of the two intensities. 
$\mathrm{BDX}-613-2411$

X-RAY FLUORESCENCE ANALYSIS OF METAL CONCENTRA, TION IN AN ALLOY ELECTROPLATING BATH, R. A. Hines, Topical, June 1980.

An energy-dispersive X-ray fluorescence analysis system has been developed for rapid, isimultaneous analysis of gold and copper

concentrations in an aqueous electroplating bath. The speed and repeatability of the isystem make it well suited for in-process ' control. Data collection and reduction are lautomatic. The analysis requires less than 10 minutes from taking the sample to printing the gold and copper concentrations.

1

I SPECIAL PROJECTS: Electrodeposition

I X-RAY FLUORESCENCE ANALYSIS OF METAL CONCENTRAITION IN AN ALLOY ELECTROPLATING BATH, R. A. Hines, Topical, BDX-613-2411, June 1980.

An energy-dispersive X-ray fluorescence analysis system has been developed for rapid, isimultaneous analysis of gold and copper concentrations in an aqueous electroplating bath. The speed and repeatability of the isystem make it. well suited for in-process control. Data collection and reduction are automatic. The analysis requires less than 10 minutes from taking the sample to printing the gold and copper concentrations. 1

1

'X-RAY FLUORESCENCE ANALYSIS OF METAL CONCENTRAITION IN AN ALLOY ELECTROPLATING BATH, R. A. IHines, Topical, BDX-613-2411, June 1980.

' An energy-dispersive X-ray fluorescence analysis system has been developed for rapid, isimultaneous analysis of gold and copper l concentrations in an aqueous electroplating 'bath. The speed and repeatability of the isystem make it well suited for in-process control. Data collection and reduction are lautomatic. The analysis requires less than 10 minutes from taking the sample to printing the gold and copper concentrations. I 